\title{
Contribution of Mouse Embryonic Stem Cells and Induced Pluripotent Stem Cells to Chimeras through Injection and Coculture of Embryos
}

\author{
Jitong Guo, ${ }^{1,2}$ Baojiang Wu, ${ }^{2}$ Shuyu Li, ${ }^{2}$ Siqin Bao, ${ }^{1,2}$ Lixia Zhao, ${ }^{2}$ \\ Shuxiang $\mathrm{Hu}^{2}$ Wei Sun, ${ }^{2}$ Jie Su, ${ }^{2}$ Yanfeng Dai, ${ }^{1,2}$ and Xihe $\mathrm{Li}^{1,2}$ \\ ${ }^{1}$ Research Center for Animal Genetic Resources of Mongolia Plateau, Inner Mongolia University, Hohhot 010021, China \\ ${ }^{2}$ Inner Mongolia Saikexing Reproductive Biotechnology Co., Ltd., Helingeer 011517, China
}

Correspondence should be addressed to Xihe Li; lixh@life.imu.edu.cn

Received 17 August 2014; Accepted 30 November 2014; Published 28 December 2014

Academic Editor: Chia-Lin Wei

Copyright (C) 2014 Jitong Guo et al. This is an open access article distributed under the Creative Commons Attribution License, which permits unrestricted use, distribution, and reproduction in any medium, provided the original work is properly cited.

Blastocyst injection and morula aggregation are commonly used to evaluate stem cell pluripotency based on chimeric contribution of the stem cells. To assess the protocols for generating chimeras from stem cells, 8-cell mouse embryos were either injected or cocultured with mouse embryonic stem cells and induced pluripotent stem cells, respectively. Although a significantly higher chimera rate resulted from blastocyst injection, the highest germline contribution resulted from injection of 8-cell embryos with embryonic stem cells. The fully agouti colored chimeras were generated from both injection and coculture of 8-cell embryos with embryonic stem cells. Additionally, microsatellite DNA screening showed that the fully agouti colored chimeras were fully embryonic stem cell derived mice. Unlike embryonic stem cells, the mouse chimeras were only generated from injection of 8-cell embryos with induced pluripotent stem cells and none of these showed germline transmission. The results indicated that injection of 8-cell embryos is the most efficient method for assessing stem cell pluripotency and generating induced pluripotent stem cell chimeras, embryonic stem cell chimeras with germline transmission, and fully mouse embryonic stem cell derived mice.

\section{Introduction}

Chimeric mice are important tools for investigating embryonic development as they can provide insights into the function of a specific gene, they can trace the origin of the cell lineage, and they can assess the potential of cells. The first chimeric mouse was produced in 1961 [1] through the aggregation of two 8-cell embryos. In later years, chimeric mice were created by microinjections of dissociated innercell-mass cells (ICMs) into the cavity of a blastocyst [2]. Since then, the techniques and protocols have been modified and improved [3-6] such that chimeric mice have been produced successfully using embryos aggregated or injected with ICM cells [2], embryonal carcinoma cells (ECCs) [7], embryonic stem cells (ESCs) [8], embryonic germ cells (EGCs) [9], somatic cell nuclear transfer-derived embryonic stem cells (ntESCs) [10], induced pluripotent stem cells (iPSCs) [11, 12], spermatogonial stem cells (SSCs) $[13,14]$, extraembryonic endoderm (XEN) cells [15], and epiblast stem cells (EpiSCs) $[16,17]$. Chimeras are a mixture of cells derived from both the donor cells and those of the recipient embryo. Since it is extremely difficult to determine the chimeric contribution of donor cells in particular tissues, chimeras are usually identified by means of coat coloration.

Conventional injection of ESCs into a blastocyst is the most popular method of producing chimeras and those generated are partially derived from the ESCs. Well sandwich aggregation is also a highly stable and reproducible method for generating germline transmitted chimeras, but two embryos are required to effect the procedure $[6,18]$. Although microinjection will also produce good germline transmitted chimeras, specialized equipment is needed. For these reasons, the coculture method was developed to produce chimeric mice $[3,4,19]$ even though it is far less efficient than the microinjection and well sandwich aggregation techniques. However, an improved method for producing chimeras with 
a high degree of chimerism and germline transmission which utilized coculture of denuded mouse embryos and ES cells in Eppendorf tubes was reported [20]. Such aggregation in Eppendorf tubes can cause embryo adhesion and form 2- or 3-embryo clusters mixed with ESCs.

Recently, 8-cell stage embryos were used to generate fully ESC-derived mice in a laser- [21] and piezo-assisted micromanipulation system [22]. The authors determined that this 8-cell method is effective for both inbred ES cells, such as C57BL/6 and 129, and hybrid ESCs to generate fully ESC-derived mice; thus, F0-generation mice enable immediate phenotyping [22]. ESCs can adhere to blastomeres and migrate into the ICM after microinjection or aggregation. Nevertheless, the mechanism of ESC migration in chimeric embryos remains unclear [23-25] and how they can completely replace the ICM of an embryo and develop into an ESC-derived mouse demands investigation. Hence, in the present study we evaluated ESC development potential and protocols for chimera generation in the production of fully ESC-derived mice. While ESCs are recognized as pluripotent stem cells, we also tested the chimeric contributions of iPSCs on chimera generation by microinjection and coculture in the well-of-the-well (WOW) system.

\section{Materials and Methods}

\subsection{Materials}

2.1.1. Animals. KM albino mice purchased from Vital River (Beijing, China) were housed at $20-24^{\circ} \mathrm{C}$ with $12 \mathrm{~h}$ of light and $12 \mathrm{~h}$ of darkness. All the experiments were carried out according to the regulatory guidelines for experimental animals approved by the State Council of China.

2.1.2. Reagents. All the chemicals used were purchased from Sigma-Aldrich (USA) unless otherwise stated. Equine chorionic gonadotropin (eCG) and human chorionic gonadotropin (hCG) were purchased from the Ningbo Sansheng Pharmaceutical Co., Ltd., China.

\subsection{Methods}

2.2.1. Culture of ESCs and iPSCs. Mouse ESC lines were isolated from the outgrowths of day 3.5 blastocysts derived from $129 / \mathrm{Sv}$ females mated to Oct $4-\triangle \mathrm{PE}-\mathrm{GFP}$ transgenic males as described $[6,26]$. Transgenic green fluorescent protein (GFP) expression by the reporter gene was under the control of the Oct4 promoter and distal enhancer, while the proximal enhancer region was deleted. This GFP transgene showed expression in the ICM of blastocysts, PGCs in vivo, and ESCs [27]. ESCs were maintained in knockout Dulbecco's modified Eagle's medium (DMEM, Gibco) containing 15\% fetal bovine serum (FBS, Gibco), 2 mM GlutaMAX, 0.1 mM 2-mercaptoethanol (Gibco), 1\% penicillin-streptomycin (Gibco), 1\% MEM nonessential amino acids (Gibco), and $1000 \mathrm{U} / \mathrm{mL}$ leukaemia inhibitory factor (LIF, ProSpec) on mitomycin C-treated mouse embryonic fibroblast (MEF) feeder cells.

Mouse iPSCs were derived from Rexl-GFP mouse MEFs (129xMF1) [28] reprogrammed by the PiggyBac transposon carrying Oct4, Sox2, Klf4, and cMyc reprogramming vectors [29]. The iPSCs were maintained in knockout DMEM (Gibco) containing 15\% FBS (Gibco), 2 mM GlutaMAX, $0.1 \mathrm{mM} 2$-mercaptoethanol (Gibco), $1 \%$ penicillinstreptomycin (Gibco), 1\% MEM nonessential amino acids (Gibco), and $1000 \mathrm{U} / \mathrm{mL}$ LIF (ProSpec) on mitomycin C-treated STO feeder cells.

Mouse ESCs and iPSCs were then frozen in FBS plus $10 \%$ dimethyl sulfoxide (DMSO). For cell injection and aggregation, thawed cells were cultured without feeder cells on a $0.1 \%$ gelatin-treated 12 -well cell culture plate (Corning) and used within 4 days. Before experiments, cells were trypsinized with $0.025 \%$ trypsin-EDTA (Gibco) and resuspended in ESCmaintaining medium.

2.2.2. Collection of Mouse Embryos. KM albino female mice 6-8 weeks old were superovulated by intraperitoneal injection of $5 \mathrm{IU}$ eCG and $5 \mathrm{IUhCG}$ at 17:00, $48 \mathrm{~h}$ apart. At the time of the hCG injection, the females were mated by KM males. Vaginal plugs were checked the following morning when the time was defined as day 0.5 post coitum $(\mathrm{dpc})$. Females with vaginal plugs were killed by cervical dislocation at 2.5 and $3.5 \mathrm{dpc}$ for collection of, respectively, 8-cell embryos and blastocysts. The oviducts or uteri were removed and transferred into $20 \mathrm{mM}$ HEPES-buffered KSOM $\quad\left(95 \mathrm{mM} \mathrm{NaCl}, \quad 2.5 \mathrm{mM} \mathrm{KCl}, \quad 0.35 \mathrm{mM} \mathrm{KH}_{2} \mathrm{PO}_{4}\right.$, $0.2 \mathrm{mM} \mathrm{MgSO}_{4} \cdot 7 \mathrm{H}_{2} \mathrm{O}, 0.2 \mathrm{mM}$ D-glucose, $10 \mathrm{mM}$ Na-lactate, $4 \mathrm{mM} \mathrm{NaHCO}_{3}, 0.2 \mathrm{mM} \mathrm{Na}$ pyruvate, $1.71 \mathrm{mM} \mathrm{CaCl} \cdot 2 \mathrm{H}_{2} \mathrm{O}$, $1.0 \mathrm{mM}$ glutamine, $\quad 0.01 \mathrm{mM} \mathrm{Na}{ }_{2}$ EDTA $2 \mathrm{H}_{2} \mathrm{O}, \quad$ and $1 \%$ penicillin and streptomycin) [30] supplemented with $3.0 \mathrm{mg} / \mathrm{mL}$ bovine serum albumin (BSA) in $35 \mathrm{~mm}$ Petri dishes (Corning). They were then flushed with a fine bore needle attached to a $1 \mathrm{~mL}$ syringe [6]. The 8-cell embryos were retrieved and cultured in 4-well dishes (Nunc) in KSOM modified with $25 \mathrm{mMNaHCO}_{3}$ and supplemented with $1.0 \mathrm{mg} / \mathrm{mL}$ BSA, $0.5 \%$ MEM nonessential amino acids (Gibco), and $0.5 \%$ essential amino acids (Gibco) at $37^{\circ} \mathrm{C}$ in a humidified atmosphere containing $5 \% \mathrm{CO}_{2}$ before being used subsequently in experiments. Blastocysts were used immediately for ESC injection.

2.2.3. Generation of Mouse Chimeras by Injection of Embryos with ESCs and iPSCs. Approximately 10-15 cells were aspirated into the injection pipette and injected gently into the blastocoel cavity using a piezo-assisted micromanipulator attached to an inverted microscope [22, 31]. The injected embryos were cultured to enable reexpansion of the blastocoel cavity and then transferred to the uteri of pseudopregnant KM mice at $2.5 \mathrm{dpc}$ [6].

In a similar manner to the injection of blastocysts, 8cell embryos were injected with cells placed carefully into the perivitelline space under the zona pellucida. The injected embryos were cultured overnight; blastocysts that developed were transferred to the uteri of pseudopregnant KM mice at $2.5 \mathrm{dpc}$ [6]. Chimeras were confirmed by the coat color pattern of the pups at birth.

2.2.4. Generation of Mouse Chimeras by Coculture of 8Cell Embryos with ESCs and iPSCs. The zona pellucida was 
TABLE 1: Sequences of primers specific for microsatellite markers.

\begin{tabular}{|c|c|c|c|c|c|}
\hline \multirow{2}{*}{ Locus } & \multirow{2}{*}{ Primer sequence $\left(5^{\prime} \rightarrow 3^{\prime}\right)$} & \multicolumn{4}{|c|}{ Conditions } \\
\hline & & Denaturation & Annealing & Number of cycles & Extension \\
\hline D2Mit296 & $\begin{array}{l}\text { CAACTGTAAATCCAGTCGTAGGG } \\
\text { CTCTGCTGAGGTTACTGTGGG }\end{array}$ & $94^{\circ} \mathrm{C}, 30 \mathrm{sec}$ & $55^{\circ} \mathrm{C}, 30 \mathrm{sec}$ & 40 & $5 \mathrm{~min}$ \\
\hline D3Mit51 & $\begin{array}{l}\text { GGCACTGATAGCAGGCCTAG } \\
\text { TCTCTTCTGGTATTTCCTTCCG }\end{array}$ & $94^{\circ} \mathrm{C}, 60 \mathrm{sec}$ & $55^{\circ} \mathrm{C}, 60 \mathrm{sec}$ & 25 & $10 \mathrm{~min}$ \\
\hline D11Mit20 & $\begin{array}{l}\text { CCTGTCCAGGTTTGAGAGGA } \\
\text { CTTGGGAGCCTCTTCGGT }\end{array}$ & $94^{\circ} \mathrm{C}, 60 \mathrm{sec}$ & $55^{\circ} \mathrm{C}, 60 \mathrm{sec}$ & 35 & $10 \mathrm{~min}$ \\
\hline D13Mit88 & $\begin{array}{l}\text { ACTGATGGCTCATGAGACCC } \\
\text { AAAATTAATAGGAACTGCAAGGG }\end{array}$ & $94^{\circ} \mathrm{C}, 30 \mathrm{sec}$ & $55^{\circ} \mathrm{C}, 30 \mathrm{sec}$ & 40 & $5 \mathrm{~min}$ \\
\hline D16Mit139 & $\begin{array}{l}\text { GTATGTAAGGAATGGTCAAATTCTTG } \\
\text { TCATTGTGATTGTGAAAGAATGC }\end{array}$ & $94^{\circ} \mathrm{C}, 30 \mathrm{sec}$ & $55^{\circ} \mathrm{C}, 30 \mathrm{sec}$ & 40 & $5 \mathrm{~min}$ \\
\hline D19Mit10 & $\begin{array}{l}\text { GCCTTTAAGCCAGTCAAGACA } \\
\text { CCAGTCTGGACTTGTGAATGA }\end{array}$ & $94^{\circ} \mathrm{C}, 3 \mathrm{sec}$ & $55^{\circ} \mathrm{C}, 30 \mathrm{sec}$ & 40 & $5 \mathrm{~min}$ \\
\hline
\end{tabular}

removed from 8-cell embryos by brief exposure to Tyrode's solution. The denuded embryos were then washed with HEPES-buffered KSOM and transferred into 4-well dishes in KSOM in one of the WOW systems [32]. Approximately 100 cells were selected and transferred into each well of the system to coculture them with the embryo overnight. The resulting blastocysts were transferred to the uteri of pseudopregnant $\mathrm{KM}$ mice at $2.5 \mathrm{dpc}$ [6]. Again, chimeras were identified by coat color of the pups at birth.

2.2.5. Embryo Transfer. Embryo transfer recipients were prepared by pairing mature KM female mice with vasectomized KM males overnight. Vaginal plugs were examined the following morning and plugged mice were used as pseudopregnant recipients for embryo transfer. They were anesthetized by intraperitoneal injection of Avertin $(0.3 \mathrm{mg} / \mathrm{g}$ body weight) and 10-15 blastocysts were transferred into the tip of each uterine horn.

2.2.6. Microsatellite DNA Analysis of Fully ESC-Derived Mice. Chimeric pups were initially identified by coat color, and the full agouti-coated mice were selected for microsatellite DNA analysis [33]. Sequences of microsatellite marker primers were obtained from the Mouse Genome Informatics website (The Jackson Laboratory, http://www.informatics.jax.org) $[34,35]$ (Table 1). Genomic DNA was extracted from tail biopsies recovered from the chimeric mice and from recipient and donor ESCs using a DNeasy Blood \& Tissue Kit (Qiagen). Microsatellite DNAs were amplified by polymerase chain reaction (PCR) using a Type-it Microsatellite PCR Kit (Qiagen). The PCR reaction was performed in a $25 \mu \mathrm{L}$ volume containing $1 \mu \mathrm{g}$ DNA, $10 \mu \mathrm{mol} / \mathrm{L}$ primers, and $12.5 \mu \mathrm{L}$ double strength master mix. Amplification was performed in 96-well microtiter plates and the PCR conditions were initialized at $94^{\circ} \mathrm{C}$ for $30-60 \mathrm{sec}$ : $25-40$ cycles of denaturation at $94^{\circ} \mathrm{C}$ for $30-60 \mathrm{sec}$, annealing at $55^{\circ} \mathrm{C}$ for $30-60 \mathrm{sec}$, and extension at $72^{\circ} \mathrm{C}$ for $1 \mathrm{~min}$, followed by a final extension step at $72^{\circ} \mathrm{C}$ for $5-$ $10 \mathrm{~min}$ (Table 1). PCR products were diluted (1:1) in loading buffer and electrophoresed in $12 \%$ polyacrylamide gels at $150 \mathrm{~V}$ for $4 \mathrm{~h} \mathrm{[36]}$. The resulting gels were then silver stained, scanned, and photographed [37]. Briefly, the gel was fixed and stained for $5 \mathrm{~min}$ in a solution containing $5 \%$ ethanol, $1 \% \mathrm{HNO}_{3}$, and $0.1 \% \mathrm{AgNO}_{3}$ and then washed in water. DNA bonds were developed for $8 \mathrm{~min}$ in developer containing $1.3 \% \mathrm{NaOH}, 0.65 \% \mathrm{NaCO}_{3}$, and $0.4 \%$ formaldehyde. Development was then stopped by addition for $1 \mathrm{~min}$ of $5 \%$ ethanol with $1 \% \mathrm{HNO}_{3}$. The gels were stored in water for photography.

2.2.7. Transmission Screening of Mouse Chimeras. Some chimeras and fully ESC-derived mice were selected and mated with KM mice. The germline transmission competence of ESCs and iPSCs was determined by the coat colors of the resulting F1 pups.

2.3. Statistical Analysis. Data expressed as percent-ages were analyzed using the chi-squared test (http://statpages.org/ ctab2x2.html). A $P$ value less than 0.05 between two groups within the same column was considered to indicate significance.

\section{Results}

3.1. Generation of Mouse Chimeras Using ESCs. When ESCs at passage 20-22 were used for chimera production (Figure 1), $29.1 \%(25 / 86), 18.1 \%(23 / 127)$, and $38.4 \%(28 / 73)$ of the pups derived from, respectively, 8-cell embryo coculture (Figure 2), 8-cell embryo injection (Figures 3(a) and 3(b)), and blastocyst injection showed coat color chimerism (Table 2). The chimeric rate from blastocyst injection was significantly higher than that from 8-cell embryo injection, but there was no significant difference between the 8-cell embryo injection and 8-cell embryo coculture groups. Three of $25(12.0 \%)$ and one of $23(4.3 \%)$ full-colored chimeras were produced by 8 -cell embryo injection and 8-cell coculture, respectively (Figure 3(c)). No full-colored chimeras were produced by blastocyst injection.

3.2. Generation of Mouse Chimeras Using iPSCs. Chimeric pups $(13.8 \%, 8 / 58)$ were produced only by injection of iPSCs at passage 10-12 in 8-cell embryos (Figure 4), although nonchimeric pups were produced in the 8-cell coculture and 


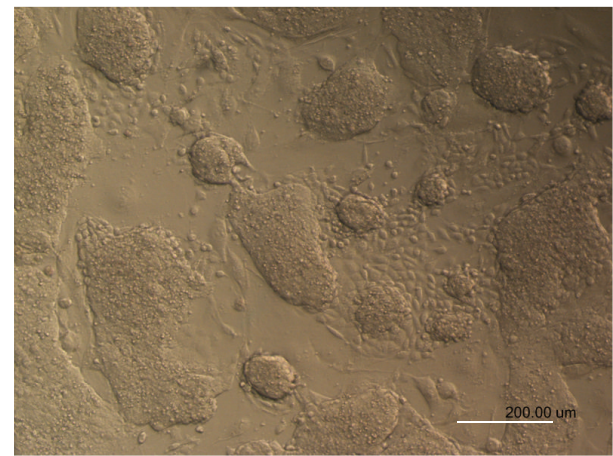

(a)

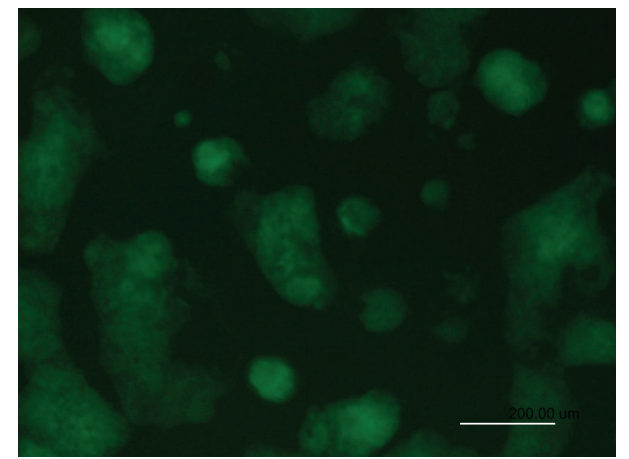

(b)

FIGURE 1: ESC and iPSC cultures without feeder cells. ES cells were cultured on day 3 after thawing: bright field (a) and GFP fluorescence (b).

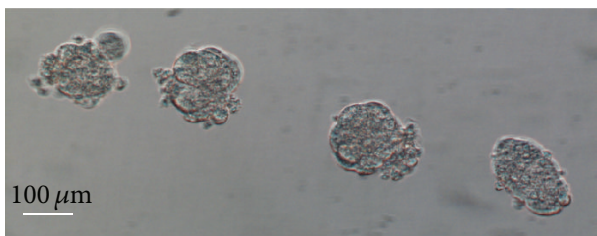

(a)

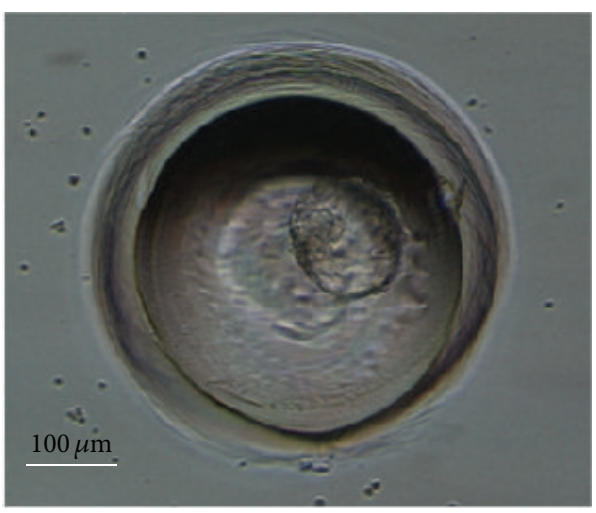

(c)

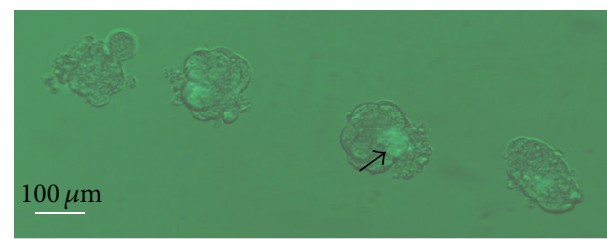

(b)

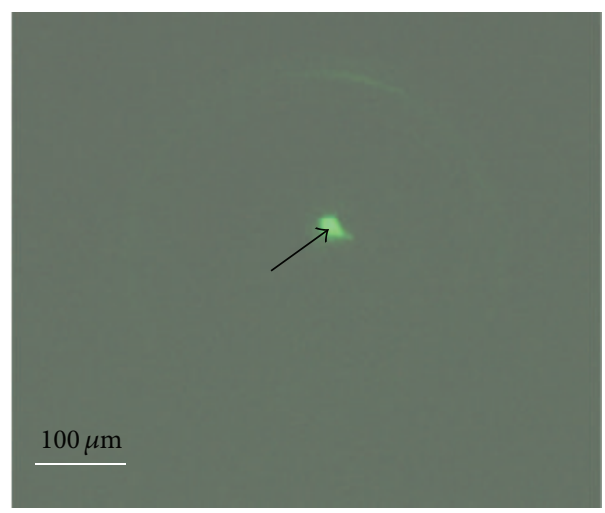

(d)

FIGURE 2: Generation of mouse chimeras by 8-cell embryo coculture with ESCs. Morulae developed from ESC coculture ((a) bright field; (b) GFP fluorescence); the arrow shows that ESCs were aggregated into the recipient embryos. Blastocysts developed from ESC coculture in the WOW system ((c) bright field; (d) GFP fluorescence). The arrow shows how ESCs were aggregated into the ICM of recipient embryos.

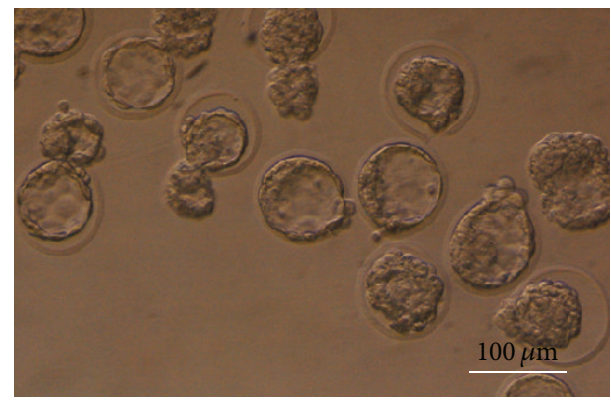

(a)

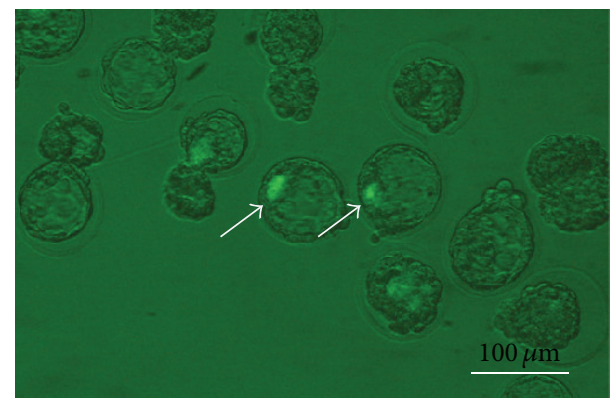

(b)

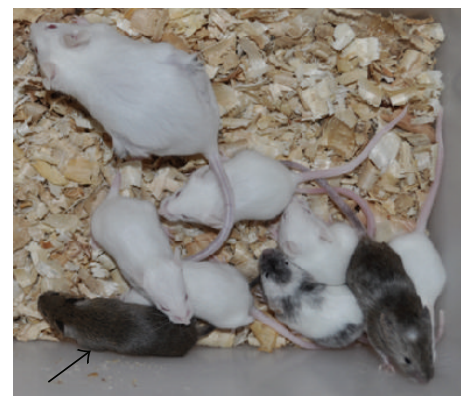

(c)

FIGURE 3: Generation of mouse chimeras by injection of ESCs into 8-cell embryos. Blastocysts developed from ES cell injection ((a) bright field; (b) GFP fluorescence). The white arrow shows that ESCs were aggregated into the ICM of blastocysts. Chimeric mice generated by injecting ESCs into 8-cell embryos (c). The black arrow shows the full agouti-colored chimeric mouse. 


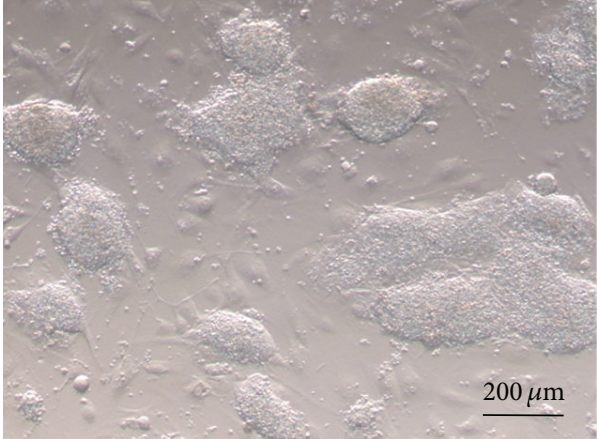

(a)

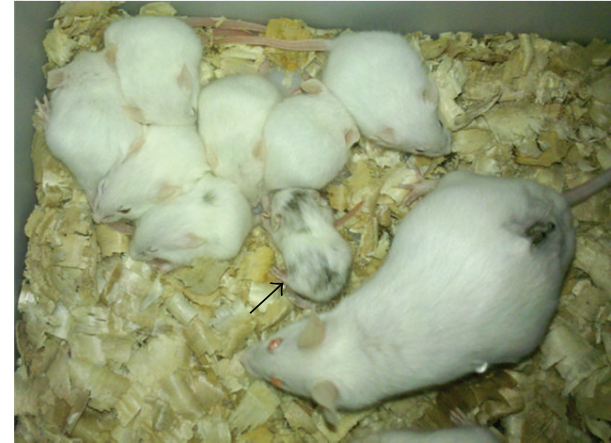

(b)

FIGURE 4: Generation of mouse chimeras with iPSCs iPS. Cells were cultured on day 3 after thawing (a). Chimeric mice generated by injection of 8-cell embryos with iPSCs (b). The black arrow shows the chimeric mouse with the colored coat.

TABLE 2: Generation of chimeric mice with ESCs.

\begin{tabular}{lcccccc}
\hline Method & $\begin{array}{c}\text { Number of embryos } \\
\text { transferred }\end{array}$ & $\begin{array}{c}\text { Number of } \\
\text { recipients }\end{array}$ & $\begin{array}{c}\text { Number of pregnant } \\
\text { recipients (\%) }\end{array}$ & \multicolumn{2}{c}{$\begin{array}{c}\text { Number of } \\
\text { pups }\end{array}$} & \multicolumn{2}{c}{$\begin{array}{c}\text { Number of chimeras (\%) } \\
\text { Total }\end{array}$} & Full colored \\
\hline 8-cell coculture & 312 & 14 & $11(78.6)^{\mathrm{a}}$ & 86 & $25(29.1)^{\mathrm{ab}}$ & $3(12.0)^{\mathrm{a}}$ \\
8-cell injection & 365 & 17 & $14(82.4)^{\mathrm{a}}$ & 127 & $23(18.1)^{\mathrm{a}}$ & $1(4.3)^{\mathrm{a}}$ \\
Blastocyst injection & 129 & 6 & $6(100)^{\mathrm{a}}$ & 73 & $28(38.4)^{\mathrm{b}}$ & $0(0.0)^{\mathrm{a}}$ \\
\hline Total & 806 & 37 & $31(83.8)$ & 286 & $76(26.6)$ & $4(1.4)$ \\
\hline
\end{tabular}

${ }^{\mathrm{a}, \mathrm{b}}$ Values with different superscripts within the same column are significantly different $(P<0.05)$.

blastocyst injection groups (Table 3). Most iPSC chimeras were fertile when mated with female KM mice, although no germline transmitting chimeras were produced.

\subsection{Microsatellite DNA Analysis of Fully ESC-Derived} Mice. Three full agouti-colored chimeras were scanned for microsatellite DNAs to determine whether they were fully ESC-derived mice. This showed that all 3 mice were fully derived from ESCs, but not from KM mouse embryos (Figure 5).

\subsection{Germline Transmission of Mouse Chimeras Derived from} ESCs. The highest germline contribution from ESCs was observed in the 8-cell embryo injection group (69.2\%, 9/13). This compared to $45.5 \%$ (5/11) for the 8-cell coculture and $8.3 \%(1 / 12)$ for the blastocyst injection groups, respectively (Table 4). No significant differences were observed in the percentages of fertile chimeras among the 8-cell embryo coculture $(78.6 \%, 11 / 14), 8$-cell embryo injection $(86.7 \%, 13 / 15)$, and blastocyst injection $(92.3 \%, 12 / 13)$ groups (Table 3$)$. However, no germline chimeras were produced from iPSCs. Germline transmission of the chimeras was assessed by the colors of the pups. The results showed that the percentage of coat colors derived from ESCs was not predictive of germline transmission (Figure 6).

\section{Discussion}

Expression of pluripotency genes, immunocytochemistry of pluripotency markers, embryoid body formation in vitro, and teratoma formation in vivo are generally used to test

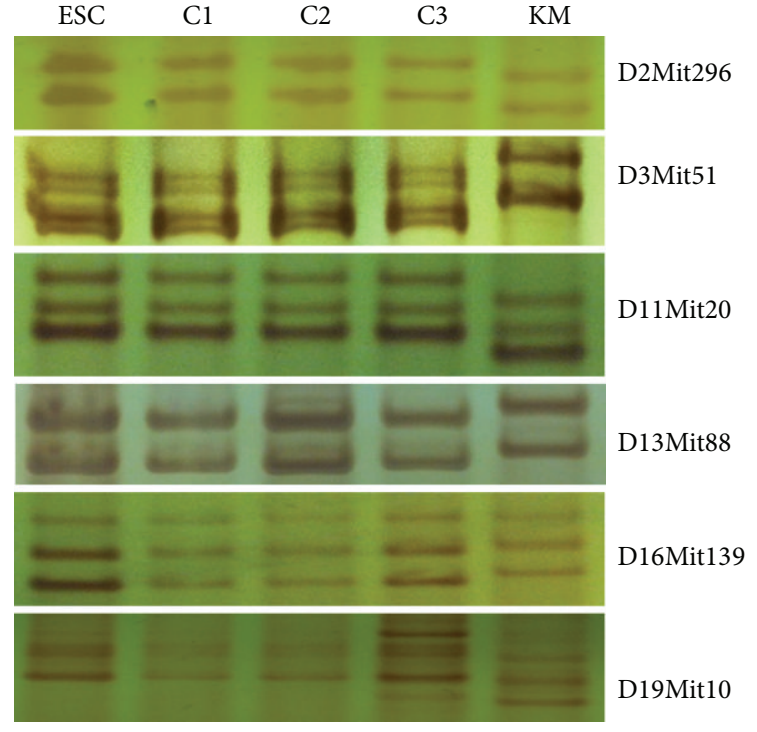

FIGURE 5: Microsatellite DNA analysis of fully ESC-derived mice. Microsatellite DNAs from cultured ESCs, three chimeric mice $(\mathrm{Cl}$, $\mathrm{C} 2$, and $\mathrm{C} 3$ ), and $\mathrm{KM}$ mouse recipient were amplified. Microsatellite loci D2Mit296, D3Mit51, D11Mit20, D13Mit88, D16Mit139, and D19Mit10 are shown.

the pluripotency of stem cells $[38,39]$. More importantly, however, their pluripotency is best evaluated based according to their contribution of cells in chimeras. Blastocyst injection and morula aggregation are the methods of choice to generate stem cell chimeras $[3,6,40]$. Our results are similar to other 
TABLE 3: Generation of chimeric mice using iPSCs.

\begin{tabular}{lccccc}
\hline Method & $\begin{array}{c}\text { Number of } \\
\text { embryos } \\
\text { transferred }\end{array}$ & $\begin{array}{c}\text { Number of } \\
\text { recipients }\end{array}$ & $\begin{array}{c}\text { Number of pregnant } \\
\text { recipients } \\
(\%)\end{array}$ & $\begin{array}{c}\text { Number of pups } \\
\text { Number of chimeras } \\
(\%)\end{array}$ \\
\hline 8-cell coculture & 341 & 16 & $1(6.3)^{\mathrm{a}}$ & 1 & $0(0)$ \\
8-cell injection & 192 & 11 & $10(90.9)^{\mathrm{b}}$ & 58 & $8(13.8)^{\mathrm{a}}$ \\
Blastocyst injection & 287 & 14 & $9(64.3)^{\mathrm{b}}$ & 142 & $0(0)^{\mathrm{b}}$ \\
\hline Total & 820 & 41 & $20(48.8)$ & $8(5.6)$ \\
\hline
\end{tabular}

${ }_{\mathrm{a}, \mathrm{b}}$ Values with different superscripts within the same column are significantly different $(P<0.05)$.

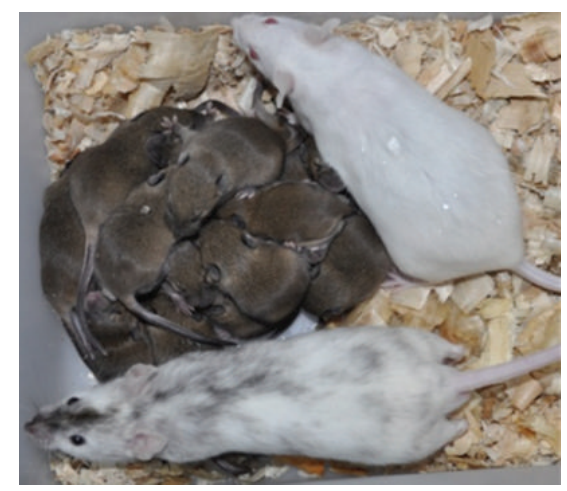

(a)

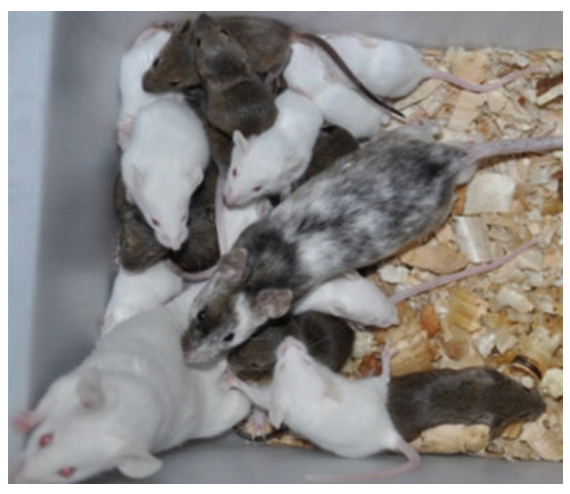

(b)

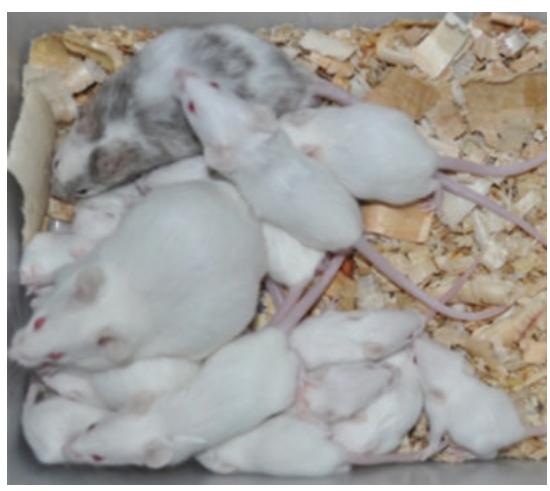

(c)

FiguRE 6: Germline transmission of mouse chimeras derived from ESCs. Fully (a), partially (b), and no (c) germline transmitted chimeric mice are shown by the colors of their pups.

TABLE 4: Germline-transmitting chimeras produced from ESCs.

\begin{tabular}{lccc}
\hline \multirow{2}{*}{ Method } & \multicolumn{3}{c}{ Germline transmission } \\
& Tested & Fertile (\%) & Germline (\%) \\
\hline 8-cell coculture & 14 & $11(78.6)^{\mathrm{a}}$ & $5(45.5)^{\mathrm{ab}}$ \\
8-cell injection & 15 & $13(86.7)^{\mathrm{a}}$ & $9(69.2)^{\mathrm{a}}$ \\
Blastocyst injection & 13 & $12(92.3)^{\mathrm{a}}$ & $1(8.3)^{\mathrm{b}}$ \\
\hline Total & 42 & $36(85.7)^{\mathrm{a}}$ & $15(75.0)$ \\
\hline a,b Values with different superscripts within the same column are significantly \\
different $(P<0.05)$.
\end{tabular}

published reports; more germline transmitted chimeras were produced from the same batch of ESCs by 8-cell embryo injection than by blastocyst injection in our experiments, despite more pups being produced by the latter [41, 42]. Eightcell embryo injection is physically more demanding than blastocyst injection due to the small size of the perivitelline space increasing the chances of damage to the blastomeres of the embryo during the injection procedure. In addition, the beginning of processes involved in compaction of mouse 8-cell embryos might be disturbed by injection of ESC. Consequently, both the ICM and the trophectoderm are unable to differentiate into normal cell types at the correct time, thereby resulting in loss of pups. This indicates that compaction of the mouse embryo is important for its further development [43] and that coculture of 8-cell embryos and ESCs is more desirable to generate transmitting chimeras from ESCs. We conclude that the aggregation modified by our method of coculture in WOW is more convenient and efficient for generating ESC chimeras and even fully ESCderived mice compared with that of blastocyst and 8-cell embryo injection $[22,44]$.

ESC chimeras were generated by 8-cell embryo injection, blastocyst injection, and 8-cell embryo coculture in this study. However, iPSC chimeras could be generated only by 8-cell embryo injection, although none of the resulting iPSC chimeras were germline transmitted. Interestingly, implantation nodules were observed when the embryos derived from 8-cell embryos cocultured with iPSCs were transferred to recipient mice but sections of these implantations showed that the fetuses had been replaced by tumorous cells (data not shown). Thus, we presume that the iPSCs, due to their oncogenicity, drove the ICM cells into tumor rather than embryo formation. iPSC chimeras can be generated by injection of 8 -cell embryos because fewer iPSCs were injected into the perivitelline space, unlike the situation in 8-cell embryo coculture. Here, a few iPSCs were induced by ICM cells which then developed into normal embryos. These results suggest that the contribution of iPSCs in chimeras does not correspond to their full pluripotency potential [45].

Our study complements the previous report that formation of the cell niche in chimeric embryos is closely associated with the dominant cells and the cell niche determines the fates of stem cells [46]. The ICM cell niche dominates the ESC's niche, but the iPSC niche is dominant to the ICM. Thus, fewer iPSCs similar to ESCs can be induced to form ICM cell-like cells and contribute to chimeras, but large numbers of iPSCs 
can induce ICM cells to transform into iPSC-like cells, which ultimately results in tumor formation.

We found that fully ESC-derived mice could be produced by coculturing and injecting 8-cell embryos but not blastocysts and that coculture is a simple and effective method for producing chimeras and fully ESC-derived mice [21, 22, 47]. This improved coculture technique is more convenient than vial coculture [20]. The finding also indicates that the protocol used has little effect on the generation of fully ESC-derived mice, but the embryonic stage has a marked effect. Consistent with other reports, ESCs can adhere to the surfaces of 8-cell embryos, but not to 2- and 4-cell embryos [25]. Although the developmental mechanism of fully ESCderived mice remains unclear, we presume that ESC clusters tend to form ICM cells due to their tight junctions [4852] and asymmetry formation derived from variation in cell sizes and shapes [53] between ESCs and blastomeres [51, 54] because more fully ESC-derived mice were generated by coculture of 8-cell embryos and ESCs in which ESC clusters aggregated with embryos were formed. Further investigation is required to determine how ES cells completely replace ICMs and develop thereafter into an ESC-derived mouse.

In conclusion, our noninvasive 8-cell embryo coculture is a simple and suitable protocol for generating ESC chimeras and fully ECS-derived mice that can be employed to characterize the totipotency of ESC lines. However, 8cell embryo injection to generate iPSC chimeras is the only suitable method for characterizing chimeric developmental potential of iPSCs. The ability of stem cells to contribute to chimeric animals may not represent the totipotency of stem cells. Transmission of stem cells and fully stem-cell-derived animals should also be considered.

\section{Conflict of Interests}

The authors declare no conflict of interests regarding the publication of this paper.

\section{Acknowledgments}

This work was supported by the grants from the Natural Science Foundation of Inner Mongolia for major special projects (2010ZD05), by the Science and Technology Innovation Fund of Inner Mongolia (20121406 and 20130216), and by the National Key Technologies R\&D Program (2012BAD12B01) of China.

\section{References}

[1] A. K. Tarkowski, "Mouse chimæras developed from fused eggs," Nature, vol. 190, no. 4779, pp. 857-860, 1961.

[2] R. L. Gardner, "Mouse chimaeras obtained by the injection of cells into the blastocyst," Nature, vol. 220, no. 5167, pp. 596-597, 1968.

[3] S. A. Wood, N. D. Allen, J. Rossant, A. Auerbach, and A. Nagy, "Non-injection methods for the production of embryonic stem cell-embryo chimaeras." Nature, vol. 365, no. 6441, pp. 87-89, 1993.
[4] S. A. Wood, W. S. Pascoe, C. Schmidt, R. Kemler, M. J. Evans, and N. D. Allen, "Simple and efficient production of embryonic stem cell-embryo chimeras by coculture," Proceedings of the National Academy of Sciences of the United States of America, vol. 90, no. 10, pp. 4582-4585, 1993.

[5] L. A. Moustafa and R. L. Brinster, "Induced chimaerism by transplanting embryonic cells into mouse blastocysts," Journal of Experimental Zoology, vol. 181, no. 2, pp. 193-201, 1972.

[6] A. Nagy, M. Gertsenstein, K. Vintersten, and R. Behringer, Manipulating the Mouse Embryo: A Laboratory Manual, Cold Spring Harbor Laboratory Press, 2003.

[7] B. Mintz and K. Illmensee, "Normal genetically mosaic mice produced from malignant teratocarcinoma cells," Proceedings of the National Academy of Sciences of the United States of America, vol. 72, no. 9, pp. 3585-3589, 1975.

[8] A. Bradley, M. Evans, M. H. Kaufman, and E. Robertson, "Formation of germ-line chimaeras from embryo-derived teratocarcinoma cell lines," Nature, vol. 309, no. 5965, pp. 255-256, 1984.

[9] Y. Matsui, K. Zsebo, and B. L. M. Hogan, "Derivation of pluripotential embryonic stem cells from murine primordial germ cells in culture," Cell, vol. 70, no. 5, pp. 841-847, 1992.

[10] T. Wakayama, V. Tabar, I. Rodriguez, A. C. F. Perry, L. Studer, and P. Mombaerts, "Differentiation of embryonic stem cell lines generated from adult somatic cells by nuclear transfer," Science, vol. 292, no. 5517, pp. 740-743, 2001.

[11] K. Okita, T. Ichisaka, and S. Yamanaka, "Generation of germline-competent induced pluripotent stem cells," Nature, vol. 448, no. 7151, pp. 313-317, 2007.

[12] K. Takahashi and S. Yamanaka, "Induction of pluripotent stem cells from mouse embryonic and adult fibroblast cultures by defined factors," Cell, vol. 126, no. 4, pp. 663-676, 2006.

[13] M. Kanatsu-Shinohara, K. Inoue, J. Lee et al., "Generation of pluripotent stem cells from neonatal mouse testis," Cell, vol. 119, no. 7, pp. 1001-1012, 2004.

[14] M. Kanatsu-Shinohara, J. Lee, K. Inoue et al., "Pluripotency of a single spermatogonial stem cell in mice," Biology of Reproduction, vol. 78, no. 4, pp. 681-687, 2008.

[15] T. Kunath, D. Arnaud, G. D. Uy et al., "Imprinted X-inactivation in extra-embryonic endoderm cell lines from mouse blastocysts," Development, vol. 132, no. 7, pp. 1649-1661, 2005.

[16] I. G. M. Brons, L. E. Smithers, M. W. B. Trotter et al., "Derivation of pluripotent epiblast stem cells from mammalian embryos," Nature, vol. 448, no. 7150, pp. 191-195, 2007.

[17] P. J. Tesar, J. G. Chenoweth, F. A. Brook et al., "New cell lines from mouse epiblast share defining features with human embryonic stem cells," Nature, vol. 448, no. 7150, pp. 196-199, 2007.

[18] B. Hogan, Manipulating the Mouse Embryo: A Laboratory Manual, Cold Spring Harbor Laboratory Press, Cold Spring Harbor, NY, USA, 1994.

[19] H. Shimada, T. Kaname, M. Suzuki et al., "Comparison of ES cell fate in sandwiched aggregates and co-cultured aggregates during blastocyst formation by monitored GFP expression," Molecular Reproduction and Development, vol. 52, no. 4, pp. 376-382, 1999.

[20] K.-H. Lee, C.-K. Chuang, H. W. Wang, L. Stone, C.-H. Chen, and C.-F. Tu, "An alternative simple method for mass production of chimeric embryos by coculturing denuded embryos and embryonic stem cells in Eppendorf vials," Theriogenology, vol. 67, no. 2, pp. 228-237, 2007. 
[21] W. T. Poueymirou, W. Auerbach, D. Frendewey et al., "F0 generation mice fully derived from gene-targeted embryonic stem cells allowing immediate phenotypic analyses," Nature Biotechnology, vol. 25, no. 1, pp. 91-99, 2007.

[22] J. Huang, K. Deng, H. Wu et al., "Efficient production of mice from embryonic stem cells injected into four-or eight-cell embryos by piezo micromanipulation," Stem Cells, vol. 26, no. 7, pp. 1883-1890, 2008.

[23] M. H. Johnson and C. A. Ziomek, "Induction of polarity in mouse 8-cell blastomeres: specificity, geometry, and stability," The Journal of Cell Biology, vol. 91, no. 1, pp. 303-308, 1981.

[24] S. Saburi, S. Azuma, E. Sato, Y. Toyoda, and C. Tachi, "Developmental fate of single embryonic stem cells microinjected into 8-cell-stage mouse embryos," Differentiation, vol. 62, no. 1, pp. 1-11, 1997.

[25] Y. de Repentigny and R. Kothary, "Production of mouse chimeras by injection of embryonic stem cells into the perivitelline space of one-cell stage embryos," Transgenic Research, vol. 19, no. 6, pp. 1137-1144, 2010.

[26] F. Tang, C. Barbacioru, S. Bao et al., "Tracing the derivation of embryonic stem cells from the inner cell mass by single-cell RNA-seq analysis," Cell Stem Cell, vol. 6, no. 5, pp. 468-478, 2010.

[27] Y. I. I. Yeom, G. Fuhrmann, C. E. Ovitt et al., "Germline regulatory element of Oct- 4 specific for the totipotent cycle of embryonal cells," Development, vol. 122, no. 3, pp. 881-894, 1996.

[28] W. Wang, J. Yang, H. Liu et al., "Rapid and efficient reprogramming of somatic cells to induced pluripotent stem cells by retinoic acid receptor gamma and liver receptor homolog 1," Proceedings of the National Academy of Sciences of the United States of America, vol. 108, no. 45, pp. 18283-18288, 2011.

[29] K. Yusa, R. Rad, J. Takeda, and A. Bradley, "Generation of transgene-free induced pluripotent mouse stem cells by the piggyBac transposon," Nature Methods, vol. 6, no. 5, pp. 363$369,2009$.

[30] G. T. Erbach, J. A. Lawitts, V. E. Papaioannou, and J. D. Biggers, "Differential growth of the mouse preimplantation embryo in chemically defined media," Biology of Reproduction, vol. 50, no. 5, pp. 1027-1033, 1994.

[31] Y. Kawase, T. Iwata, M. Watanabe, N. Kamada, O. Ueda, and H. Suzuki, "Application of the piezo-micromanipulator for injection of embryonic stem cells into mouse blastocysts," Contemporary Topics in Laboratory Animal Science, vol. 40, no. 2, pp. 31-34, 2001.

[32] G. Vajta, T. T. Peura, P. Holm et al., "New method for culture of zona-included or zona-free embryos: the Well of the Well (WOW) system," Molecular Reproduction and Development, vol. 55, no. 3, pp. 256-264, 2000.

[33] X. Zhang, Z. Zhu, Z. Huang, P. Tan, and R. Z. Ma, "Microsatellite genotyping for four expected inbred mouse strains from KM mice," Journal of Genetics and Genomics, vol. 34, no. 3, pp. 214222, 2007.

[34] C. Matouk, D. Gosselin, D. Malo, E. Skamene, and D. Radzioch, "PCR-analyzed microsatellites for the inbred mouse strain $129 / \mathrm{Sv}$, the strain most commonly used in gene knockout technology," Mammalian Genome, vol. 7, no. 8, pp. 603-605, 1996.

[35] E. M. Simpson, C. C. Linder, E. E. Sargent, M. T. Davisson, L. E. Mobraaten, and J. J. Sharp, "Genetic variation among 129 substrains and its importance for targeted mutagenesis in mice," Nature Genetics, vol. 16, no. 1, pp. 19-27, 1997.
[36] A. M. Guilliatt, "Agarose and polyacrylamide gel electrophoresis," in Methods in Molecular Biology, vol. 187, pp. 1-11, Humana Press, Totowa, NJ, USA, 2002.

[37] Z. W. An, L. L. Xie, H. Cheng et al., "A silver staining procedure for nucleic acids in polyacrylamide gels without fixation and pretreatment," Analytical Biochemistry, vol. 391, no. 1, pp. 77-79, 2009.

[38] O. Adewumi, B. Aflatoonian, L. Ahrlund-Richter et al., "Characterization of human embryonic stem cell lines by the international stem cell initiative," Nature Biotechnology, vol. 25, no. 7, pp. 803-816, 2007.

[39] M. Martí, L. Mulero, C. Pardo et al., "Characterization of pluripotent stem cells," Nature Protocols, vol. 8, no. 2, pp. 223253, 2013.

[40] A. C. Carstea, M. K. Pirity, and A. Dinnyes, "Germline competence of mouse ES and iPS cell lines: chimera technologies and genetic background," World Journal of Stem Cells, vol. 1, no. 1, pp. 22-29, 2009.

[41] T. Tokunaga and Y. Tsunoda, "Efficacious production of viable germ-line chimeras between embryonic stem (ES) cells and 8cell stage embryos," Development Growth and Differentiation, vol. 34, no. 5, pp. 561-566, 1992.

[42] T. Yagi, T. Tokunaga, Y. Furuta et al., "A novel ES cell line, TT2, with high germline-differentiating potency," Analytical Biochemistry, vol. 214, no. 1, pp. 70-76, 1993.

[43] N. Saiz and B. Plusa, "Early cell fate decisions in the mouse embryo," Reproduction, vol. 145, no. 3, pp. R65-R80, 2013.

[44] M. A. Ramírez, R. Fernández-González, M. Pérez-Crespo, E. Pericuesta, and A. Gutiérrez-Adán, "Effect of stem cell activation, culture media of manipulated embryos, and site of embryo transfer in the production of F0 embryonic stem cell mice," Biology of Reproduction, vol. 80, no. 6, pp. 1216-1222, 2009.

[45] M. Tachibana, M. Sparman, C. Ramsey et al., "Generation of chimeric rhesus monkeys," Cell, vol. 148, no. 1-2, pp. 285-295, 2012.

[46] D. James, S. A. Noggle, T. Swigut, and A. H. Brivanlou, "Contribution of human embryonic stem cells to mouse blastocysts," Developmental Biology, vol. 295, no. 1, pp. 90-102, 2006.

[47] T. M. DeChiara, W. T. Poueymirou, W. Auerbach, D. Frendewey, G. D. Yancopoulos, and D. M. Valenzuela, "Producing fully ES cell-derived mice from eight-cell stage embryo injections," Methods in Enzymology, vol. 476, pp. 285-294, 2010.

[48] B. Plusa, S. Frankenberg, A. Chalmers et al., "Downregulation of Par3 and aPKC function directs cells towards the ICM in the preimplantation mouse embryo," Journal of Cell Science, vol. 118, no. 3, pp. 505-515, 2005.

[49] T. P. Fleming, D. R. Garrod, and A. J. Elsmore, "Desmosome biogenesis in the mouse preimplantation embryo," Development, vol. 112, no. 2, pp. 527-539, 1991.

[50] M. H. Johnson, B. Maro, and M. Takeichi, "The role of cell adhesion in the synchronization and orientation of polarization in 8-cell mouse blastomeres," Journal of Embryology and Experimental Morphology, vol. 93, pp. 239-255, 1986.

[51] S. A. Morris, R. T. Y. Teo, H. Li, P. Robson, D. M. Glover, and M. Zernicka-Goetz, "Origin and formation of the first two distinct cell types of the inner cell mass in the mouse embryo," Proceedings of the National Academy of Sciences of the United States of America, vol. 107, no. 14, pp. 6364-6369, 2010.

[52] M. Zernicka-Goetz, "First cell fate decisions and spatial patterning in the early mouse embryo," Seminars in Cell and Developmental Biology, vol. 15, no. 5, pp. 563-572, 2004. 
[53] C. A. Ziomek and M. H. Johnson, "Cell surface interaction induces polarization of mouse 8-cell blastomeres at compaction," Cell, vol. 21, no. 3, pp. 935-942, 1980.

[54] T. Ducibella and E. Anderson, "Cell shape and membrane changes in the eight cell mouse embryo: prerequisites for morphogenesis of the blastocyst," Developmental Biology, vol. 47, no. 1, pp. 45-58, 1975. 

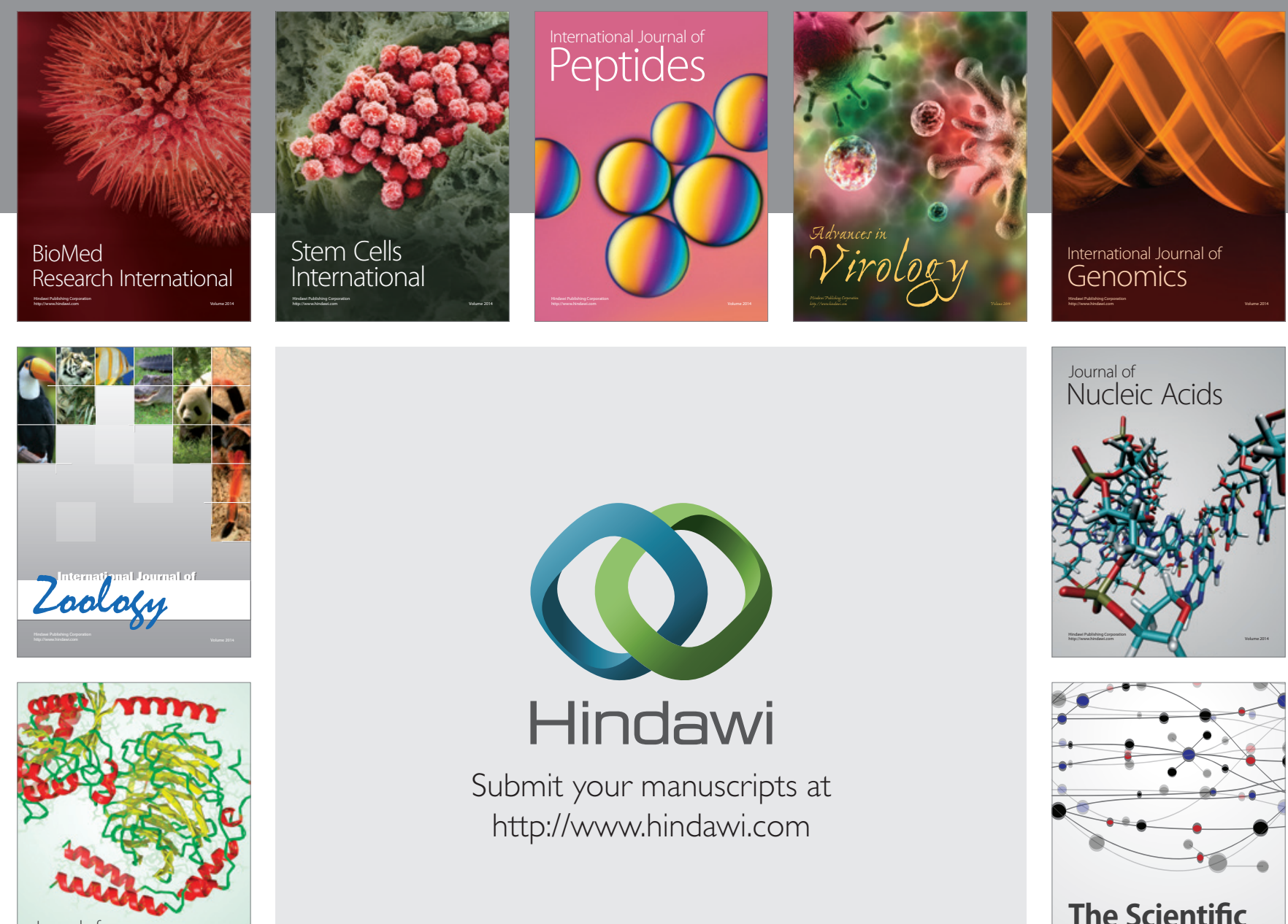

Submit your manuscripts at

http://www.hindawi.com

Journal of
Signal Transduction
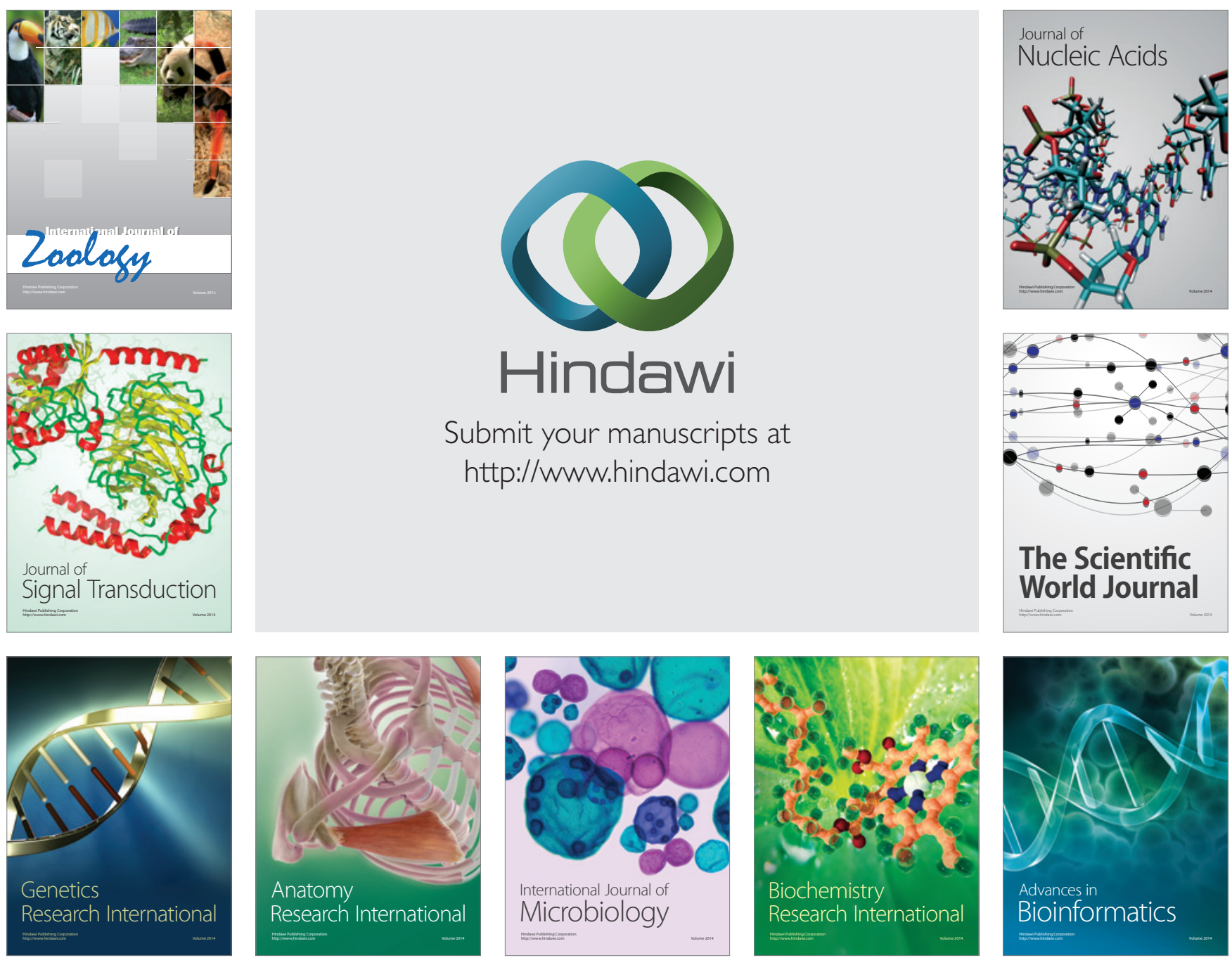

The Scientific World Journal
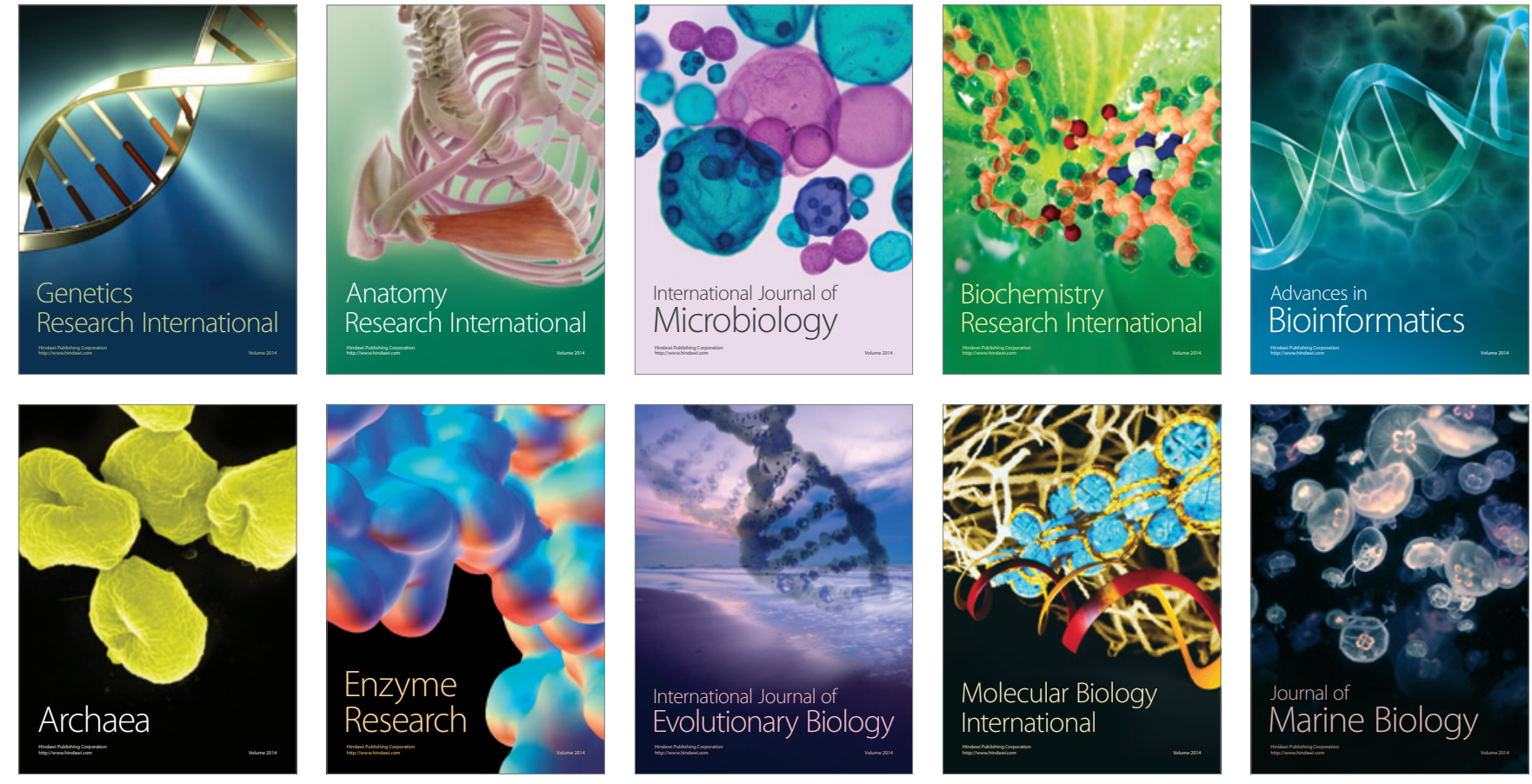